\title{
GAMBARAN KECERDASAN EMOSIONAL PADA SISWA SMKN 1 JAKARTA
}

\author{
Dwi Wulandari \\ Psikologi Pendidikan, Fakultas Ilmu Pendidikan, Universitas Negeri Jakarta \\ Jl. Sunter Bentengan V Rt. 005/05, No. 7, Jakarta Utara \\ E-mail : Landa.chiby@yahoo.com
}

\begin{abstract}
The aim of this article is to know the description of emotional intelligence to vocational high school's students in Jakarta. This research took at SMKN 1 Jakarta from February 2012 until June 2012. Populations of the research are 800 students which are the student's entire of SMKN 1 Jakarta. Sample in this research are 50 students from first and second grades.

Researcher uses a description method by quantitative approach. Technique to take the sample is by using incidental sampling technique. To collect the emotional intelligence's data, researcher uses an emotional intelligence's scale by likert and then, analyze it with statistic description. The result shows that SMKN 1 Jakarta's students have a high emotional intelligence. The data shows that 50 respondences $(100 \%)$ have a high level category of emotional intelligence.
\end{abstract}

Keywords : Emotional Intelligence, Vocational High School's Students

\section{Pendahuluan}

SMKN 1 Jakarta merupakan salah satu sekolah tertua yang masih mempertahankan bangunan kuno khas peninggalan Belanda. Sekolah ini cenderung dicap negatif karena siswanya seringkali terlibat tawuran dengan sekolah lain. Buruknya "reputasi" SMKN 1 Jakarta terdengar hingga ke telinga pejabat Kementerian Pendidikan. Niat untuk memperbaiki citra sekolah pun mulai tampak pada tanggal 18 Agustus 2009, saat pemerintah menjadikan SMKN 1 Jakarta sebagai sekolah RSBI (Rintisan Sekolah Bertaraf Internasional).

Berawal dari sekolah yang terkenal dengan budaya tawuran, SMKN 1 Jakarta menjelma menjadi sekolah kejuruan unggulan di bidang teknologi. Pada tahun 2010 dengan dukungan dari pemerintah, SMKN 1 Jakarta mengembangkan diri mulai dari perawatan hingga perbaikan bangunan dan fasilitas. Semua usaha SMKN 1 Jakarta dalam berbenah tidak sia-sia. Tak perlu waktu lama bagi sekolah ini untuk menuai hasilnya. Pada tahun 2010, SMKN 1 Jakarta meraih beberapa juara untuk perlombaan Olimpiade Sains Terapan tingkat Nasional (OSTN). Berikut prestasi yang mampu diraih oleh SMKN 1 Jakarta :

Tabel 1. Prestasi yang diraih SMKN 1 Jakarta

\begin{tabular}{ccc}
\hline No. & Mata Pelajaran & Juara \\
\hline 1. & Kimia Terapan & I dan II \\
2. & Matematika & III \\
3. & Fisika Terapan & III \\
4. & Matematika Teknologi & I \\
\hline
\end{tabular}


Prestasi ini disertai dengan kepercayaan yang diberikan Direktorat Pembinaan Sekolah Menengah Kejuruan Kementerian Pendidikan Nasional, SMKN 1 Jakarta dilibatkan dalam program Esemka. Sebanyak dua guru dan lima siswa terlibat dalam perancangan, pembuatan, dan perakitan mesin Esemka. Mereka dipercaya merakit 15 dari 1.000 mesin yang dikerjakan dalam program Esemka. Sejak itu identitas SMKN 1 Jakarta yang terkenal suka tawuran semakin luntur.

Sekolah dapat dikatakan unggul apabila sekolah tersebut memiliki kemauan dan kemampuan dalam menyesuaikan semua praktek sekolah dengan perbedaan individual dalam perkembangan fisik, kognitif dan sosial muridmuridnya (Santrock, 2002: 16). Aspek lain dari SMK yang efektif adalah menekankan pentingnya menciptakan lingkungan yang positif bagi perkembangan sosial dan emosional remaja (Santrock, 2002: 18).

Tujuan ini ditetapkan tidak hanya karena lingkungan semacam ini memberi kontribusi bagi keunggulan akademis, tetapi juga karena perkembangan sosial dan emosional dinilai sebagai sesuatu yang secara intrinsik penting dalam sekolah bagi remaja. Kebijakan-kebijakan sekolah semacam ini mencerminkan perhatian dan kepedulian pribadi terhadap orang-orang yang memiliki kebutuhankebutuhan perkembangan yang mendesak khususnya remaja (Santrock, 2002: 18).

Masa remaja merupakan masa perjalanan dari masa kanak-kanak ke masa dewasa ditandai oleh periode transisional panjang. Masa remaja dimulai pada usia 11 atau 12 sampai dengan 20 tahun, dan masa tersebut membawa perubahan besar saling bertautan dalam semua ranah perkembangan (Papalia, Old \& Feldman, 2008: 534). Masa remaja dikenal dengan masa storm and stress dimana terjadi ketegangan emosi yang meninggi sebagai akibat dari perubahan fisik dan kelenjar hormon. Kondisi ini disebabkan karena remaja di bawah tekanan sosial dan menghadapi kondisi baru (Wahyuni, 2005: 178).

Masa remaja yang identik dengan lingkungan sosial tempat berinteraksi, membuat mereka dituntut untuk dapat menyesuaikan diri secara efektif. Pada umumnya masa remaja lebih banyak menghabiskan waktunya di sekolah. Sekolah adalah lingkungan pendidikan sekunder. Sekolah menawarkan peluang untuk belajar informasi, menguasai keterampilan baru, dan menajamkan keterampilan yang sudah ada. Sekolah tidak hanya memberi kontribusi bagi keunggulan akademis, tetapi juga karena perkembangan sosial dan emosional dinilai sebagai sesuatu yang secara intrinsik penting dalam sekolah bagi remaja. Tidak mengherankan kalau pengaruh sekolah terhadap perkembangan remaja cukup besar (Sarlito, 2002: 124).

Dalam memenuhi tugas perkembangan masa remaja, khususnya siswa SMK, kecerdasan emosional sangat berperan penting. Goleman menyatakan, keberhasilan dalam hidup tidak hanya ditentukan oleh IQ, tetapi kecerdasan emosional lah yang memegang peranan (Goleman, 2003: 38). Kecerdasan emosional dilontarkan pertama kali pada tahun 1990 oleh psikolog Peter Salovey dari Harvard University untuk menerangkan kualitaskualitas emosional yang tampaknya penting bagi keberhasilan (Shapiro, 2003: 5). Salovey dan Mayer (dalam Shapiro, 2003: 8) mengatakan "kecerdasan emosional adalah himpunan bagian dari kecerdasan sosial yang melibatkan kemampuan memantau perasaan sosial yang melibatkan kemampuan pada orang lain, memilah-milah semuanya dan menggunakan informasi ini untuk membimbing pikiran dan tindakan."

Kecerdasan emosional adalah kemampuan individu untuk dapat memotivasi diri sendiri, bertahan menghadapi frustasi, mengendalikan 
dorongan hati dan tidak melebih-lebihkan kesenangan, mengatur suasana hati dan menjaga agar bebas stres, tidak melumpuhkan kemampuan berfikir, berempati dan berdoa (Goleman, 2003: $45)$.

Menurut Reuven Bar-On (dalam Stain dan Book, 2002: 157-158)), kecerdasan emosional adalah serangkaian kemampuan, kompetensi dan kecakapan non-kognitif, yang mempengaruhi kemampuan seseorang untuk berhasil mengatasi tuntutan dan tekanan lingkungan.

Dilanjutkan oleh Conny R. Semiawan (1997: 153) yang mengemukakan bahwa kecerdasan emosional sebagai "kemampuan membaca pikiran diri sendiri dan pikiran orang lain sehingga mampu menempatkan diri dalam situasi orang lain dan mampu mengendalikan diri."

Menurut Salovey dan Mayer (dalam Goleman, 2003: 57-59), ada lima aspek dalam kecerdasan emosional yaitu:

1. Mengenali emosi diri

Kemampuan individu untuk mengenali perasaan diri sendiri sewaktu perasaan itu terjadi, serta mengetahui penyebab terjadinya. Kemampuan ini merupakan dasar dari kecerdasan emosional. Para ahli psikologi menyebutkan kesadaran diri yakni kesadaran individu akan emosinya sendiri. Orang yang mampu memantau emosinya secara cermat adalah orang yang dapat mengendalikan hidupnya, mereka tidak hanya sadar akan perasaan dirinya, namun mereka juga sadar akan pikiran dan tindakan yang mereka lakukan. Kesadaran diri mencakup kemampuan mengenali emosi diri sendiri, menerima diri sendiri, mengenali hubungan antara perasaan dan tindakan.

\section{Mengelola emosi}

Kemampuan individu dalam menangani perasaan agar dapat terungkap dengan tepat, sehingga tercapai keseimbangan dalam dirinya. Untuk memiliki keterampilan ini sebelumnya individu harus menguasai kesadaran diri terhadap emosi yang dirasakannya. Kemampuan mengelola emosi mencakup kemampuan untuk menghibur diri sendiri, mengendalikan rasa marah, melepaskan kecemasan, kemurungan atau ketersinggungan dan akibat-akibat yang ditimbulkannya serta kemampuan untuk bangkit dari perasaan-perasaan yang menekan. Orang yang memiliki kemampuan ini mampu bangkit dari keterpurukan yang sedang dialaminya. Mengelola emosi mencakup kemampuan untuk menerima kegagalan, mengelola perasaan, dan menyelesaikan masalah.

3. Memotivasi diri sendiri

Motivasi diri adalah kemampuan individu untuk mengendalikan dorongan hati, menunda kepuasan, mengatur suasana hati, memotivasi diri untuk bertahan dan terus berusaha menemukan banyak cara untuk mencapai tujuan (Goleman, 2003: 134). Ciri-ciri individu yang memiliki kemampuan ini adalah memiliki kepercayaan diri yang tinggi, optimis dalam menghadapi keadaan yang sulit, cukup terampil, inisiatif dan bertindak sangat efektif dalam menemukan cara alternatif agar sasaran tercapai. (Goleman, 2003: 114) Orang yang memiliki keterampilan ini cenderung lebih produktif dan efektif dalam hal apapun yang mereka kerjakan. Motivasi diri mencakup kemampuan untuk meningkatkan prestasi, 
menumbuhkan optimisme, dan mempunyai tanggung jawab.

4. Empati

Kemampuan individu untuk mengenali emosi orang lain disebut juga empati. Individu yang memiliki kemampuan empati lebih mampu menangkap sinyal-sinyal sosial tersembunyi yang mengisyaratkan apa saja yang dibutuhkan atau dikehendaki orang lain. Kunci untuk memahami perasaan orang lain adalah mampu membaca pesan nonverbal, nada bicara, gerak-gerik, ekspresi wajah dan sebagainya. Menurut penelitian Robert Rosenthal (dalam Goleman, 2003: 136), menunjukkan bahwa orang-orang yang mampu membaca perasaan dan isyarat non verbal lebih mampu menyesuaikan diri secara emosional, lebih populer, lebih mudah bergaul, dan lebih peka. Empati mencakup kemampuan mengenali emosi orang lain, memiliki rasa peduli terhadap orang lain, dan menghargai pendapat orang lain.

5. Membina hubungan

Membina hubungan adalah kemampuan individu untuk mengelola emosi orang lain dengan baik ketika berhubungan dan dengan cermat membaca situasi, serta mampu berinteraksi dengan lancar. Kemampuan dalam membina hubungan merupakan suatu keterampilan yang menunjang popularitas, kepemimpinan dan keberhasilan antar pribadi. Orang-orang yang hebat dalam keterampilan membina hubungan ini akan sukses dalam bidang apapun. Orang-orang ini populer dalam lingkungannya dan menjadi teman yang menyenangkan karena kemampuannya dalam berkomunikasi.
Sejauhmana perkembangan kepribadian individu dapat dilihat dari banyaknya hubungan interpersonal yang dilakukan. Membina hubungan mencakup kemampuan mempunyai relasi dengan orang lain, mampu bekerjasama, dan menyelesaikan konflik dengan orang lain.

Kecerdasan atau kompetensi seseorang dipengaruhi oleh dua faktor utama yaitu faktor internal yaitu faktor pembawaan yang bersifat genetik dan faktor eksternal yaitu faktor yang mempengaruhi perkembangan kecerdasan seseorang secara akumulatif sejak kecil seperti pendidikan dan pengalaman yang dimiliki seseorang.

Faktor genetik mempengaruhi seseorang menggunakan pemikiran intelektual dan emosinya. Pengendalian emosi dengan kecerdasan emosional (emotional intelligence) dapat mempengaruhi keseimbangan antara penggunaan pusat emosi (amygdala) dan penggunaan pemikiran intelektual (prefrontal neocortex). Dengan mengendalikan emosi, seseorang dapat mengatur kapan dia harus lebih banyak menggunakan pemikiran intelektual yang bersifat kognitif dan kapan dia dapat menggunakan emosi (Hutapea \& Thoha, 2008: xvi).

Menurut Goleman (2003: 268), sekolah pertama untuk mempelajari emosi adalah kehidupan keluarga. Semua interaksi sekecil apapun antara orang tua dan anak mempunyai nilai emosional, dan dalam pengulangan pesan selama bertahun-tahun pada anak akan membentuk pandangan hidup serta kemampuan emosionalnya. Anak adalah murid yang pintar, mereka sangat peka terhadap transmisi emosi yang paling halus sekali pun dalam kehidupan keluarga. Pembelajaran emosi yang diterima anak bukan hanya melalui hal-hal yang diucapkan atau dilakukan orang tua secara 
langsung, melainkan juga contoh-contoh yang diberikan orang tua sewaktu menangani perasaannya sendiri. Faktor lain yang mempengaruhi proses perkembangan emosional adalah sekolah dan masyarakat. Dalam lingkungan tersebut seseorang belajar bagaimana merasakan perasaan diri sendiri dan bagaimana orang lain menanggapi perasaan tersebut, bagaimana berpikir tentang perasaan-perasaan itu dan pilihan-pilihan apa yang dimiliki untuk bereaksi, serta bagaimana membaca dan mengungkapkan harapan dan rasa takut.

Mengingat bahwa masa remaja merupakan masa yang paling banyak dipengaruhi oleh lingkungan keluarga dan teman-teman sebaya, maka untuk menghindari hal-hal negatif yang dapat merugikan dirinya sendiri dan orang lain, remaja hendaknya memahami dan memiliki apa yang disebut kecerdasan emosional.

Kecerdasan emosional ini terlihat dalam halhal seperti bagaimana remaja mampu untuk memberi kesan yang baik tentang dirinya, mampu mengungkapkan dengan baik emosinya sendiri, berusaha menyetarakan diri dengan lingkungan, dapat mengendalikan perasaan dan mampu mengungkapkan reaksi emosi sesuai dengan waktu dan kondisi yang ada sehingga interaksi dengan orang lain dapat terjalin dengan lancar dan efektif. Menurut Daradjat (dalam Kasdin, 1999: 11), kemampuan mengendalikan emosi merupakan kebutuhan yang harus dimiliki oleh remaja. Dengan kemampuan inilah remaja akan mempunyai sikap yang lebih stabil.

Banyak bukti memperlihatkan bahwa individu yang cakap secara emosional mampu mengetahui dan menangani perasaan mereka sendiri dengan baik, serta mampu membaca dan menghadapi perasaan orang lain secara efektif.
Individu dengan keterampilan emosional yang berkembang baik berarti kemungkinan besar ia akan berhasil dalam pelajaran, menguasai kebiasaan pikiran yang mendorong produktivitas mereka. Sebaliknya siswa yang tidak dapat menghimpun kendali tertentu atas kehidupan emosionalnya akan mengalami pertarungan batin yang merampas kemampuan mereka untuk berkonsentrasi pada pelajaran ataupun untuk memiliki pikiran yang jernih, sehingga bagaimana siswa diharapkan berprestasi kalau mereka masih kesulitan mengatur emosi mereka (Goleman, 2003: 48).

Berdasarkan paparan teori ditas, penelitian ini bertujuan untuk mengetahui gambaran kecerdasan emosional pada siswa SMKN 1 Jakarta.

\section{Metode Penelitian}

Penelitian ini menggunakan metode kuantitatif dengan pendekatan deskriptif. Penelitian ini dilakukan di SMKN 1 Jakarta. Subjek dalam penelitian ini adalah siswa kelas X dan XI SMKN 1 Jakarta. Teknik pengambilan sampel yang digunakan dalam penelitian ini adalah insidental sampling. Sampel yang dijadikan sumber data sebanyak 50 orang. Berikut ini data sampel yang dijadikan sumber data dalam penelitian ini :

\section{Tabel 2. Data Sampel Penelitian}

\begin{tabular}{ccc}
\hline $\begin{array}{c}\text { Jenjang } \\
\text { Kelas }\end{array}$ & Frekuensi & $\begin{array}{c}\text { Persentase } \\
(\%)\end{array}$ \\
\hline $\mathbf{X}$ & 30 & 60 \\
XI & 20 & 40 \\
Total & $\mathbf{5 0}$ & $\mathbf{1 0 0}$ \\
\hline
\end{tabular}

Teknik pengumpulan data dalam penelitian ini menggunakan skala. Skala pengukuran yang digunakan oleh peneliti adalah model likert. Dalam penelitian ini, alat yang digunakan untuk mengukur 
kecerdasan emosional adalah Emotional Intelligence Inventory (EII) yang dimodifikasi oleh peneliti, berdasarkan konsep yang diajukan Goleman. Analisis data statistik yang digunakan dalam penelitian ini adalah perhitungan kategorisasi skor keseluruhan aspek yang digolongkan berdasarkan dua kategori, yaitu tinggi dan rendah. Penentuan katergorisasi skor ini dilihat dengan cara membandingkan nilai yang diperoleh dengan mean teoritiknya. Apabila nilai $\mathrm{x}>$ (mean teoritik) maka tergolong dalam kategori tinggi, begitu juga sebaliknya apabila nilai $\mathrm{x}<$ (mean teoritik) maka tergolong dalam kategori rendah. Perhitungan kategorisasi skor dilakukan dengan cara manual maupun dengan menggunakan program perhitungan SPSS versi 12 .

\section{Hasil dan Diskusi}

Penelitian dimulai dari bulan Februari sampai dengan Juni 2012. Total sampel yang disebar sebanyak 50. Data yang diperoleh berupa skor kecerdasan emosional siswa, dideskripsikan menurut pemusatan dan penyebarannya. Hasilnya dapat dilihat pada tabel berikut :

Tabel 3. Pemusatan dan Penyebaran Skor Kecerdasan Emosional

\begin{tabular}{llr}
\hline $\mathrm{N}$ & Valid & 50 \\
& Missing & 0 \\
Mean & & 168,0200 \\
Median & & 167,0000 \\
Mode & 167,00 \\
Std. Deviation & & 11,18580 \\
Variance & 125,122 \\
Range & 50,00 \\
Minimum & & 148,00 \\
Maximum & & 198,00 \\
Sum & & 8401,00 \\
Percentiles & 30 & 160,0000 \\
\hline
\end{tabular}

Dari keseluruhan skor kecerdasan emosional siswa SMKN 1 Jakarta, diperoleh rata-rata (mean ) skor yaitu 168,02, sedangkan skor terbanyak adalah 167. Standar deviasi yang diperoleh dari perhitungan adalah 11, 186 .

Berikut deskripsi frekuensi skor kecerdasan emosional siswa dari hasil perhitungan dengan menggunakan program SPSS versi 12 :

Tabel 4. Distribusi Frekuensi Skor

Kecerdasan Emosional Siswa SMKN 1 Jakarta

\begin{tabular}{cccccc}
\hline No. & $\begin{array}{c}\text { Interval } \\
\text { Skor }\end{array}$ & $\begin{array}{c}\text { Kelas } \\
\text { Atas }\end{array}$ & $\begin{array}{c}\text { Kelas } \\
\text { Bawah }\end{array}$ & Frekuensi & $\begin{array}{c}\text { Persentase } \\
(\%)\end{array}$ \\
\hline 1. & $148-154$ & 153,5 & 147,5 & 4 & 8 \\
\hline 2. & $155-161$ & 160,5 & 154,5 & 13 & 26 \\
\hline 3. & $162-168$ & 167,5 & 161,5 & 12 & 24 \\
\hline 4. & $169-175$ & 174,5 & 168,5 & 7 & 14 \\
\hline 5. & $176-182$ & 181,5 & 175,5 & 9 & 18 \\
\hline 6. & $183-189$ & 188,5 & 182,5 & 4 & 8 \\
\hline 7. & $190-196$ & 195,5 & 189,5 & - & - \\
\hline 8. & $197-203$ & 202,5 & 196,5 & 1 & 2 \\
& \multicolumn{5}{c}{ Total } \\
\hline
\end{tabular}

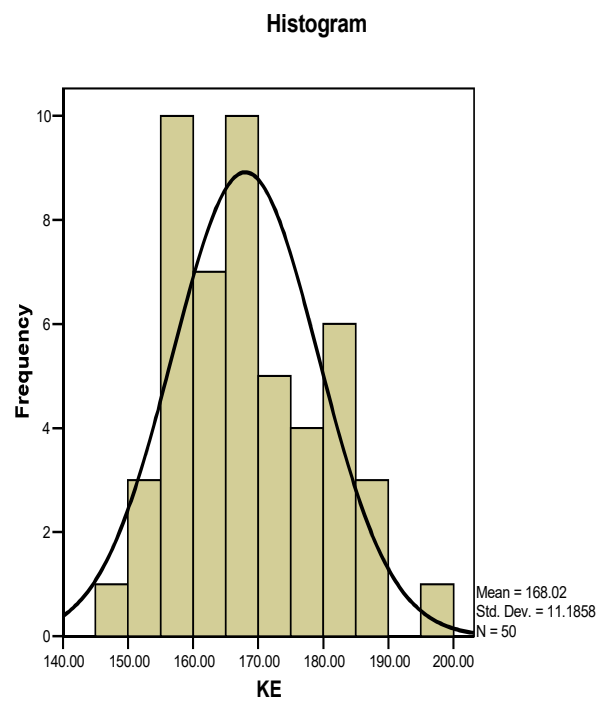

Gambar 1. Grafik Skor Kecerdasan emosional Siswa SMKN 1 Jakarta 
Berdasakan tabel dan gambar di atas, maka dapat diketahui bahwa skor kecerdasan emosional tertinggi adalah 198 dan terendah 148, sedangkan skor kecerdasan emosional terbanyak adalah 26\% siswa yang memiliki skor kecerdasan emosional 155-161 (13 orang)

Data tersebut kemudian dikelompokkan berdasarkan kategorisasi skor kecerdasan emosional. Sebelum dikategorisasikan, terlebih dahulu dilakukan uji normalitas guna untuk menguji bahwa data sampel berasal dari populasi yang terdistribusi normal atau tidak. Uji normalitas dilakukan dengan menggunakan uji Shapiro-Wilk, karena jumlah sampel penelitian kurang dari 100. Berikut hasil uji normalitas data :

Tabel 5. Hasil Uji Normalitas

\begin{tabular}{lccc}
\hline & \multicolumn{3}{c}{ Shapiro-Wilk } \\
\cline { 2 - 4 } KE & Statistic & $\mathrm{df}$ & Sig. \\
\hline
\end{tabular}

Tabel diatas menunjukkan bahwa nilai signifikansi $>0,05$, maka data berdistribusi normal. Berdasarkan uji normalitas data, data skor kecerdasan emosional terdistribusi normal, maka kriteria skor kecerdasan emosional berdasarkan kategorisasi ordinal dengan asumsi data terdistribusi normal.

Tabel 6. Kategorisasi Skor Kecerdasan

Emosional Siswa SMKN 1 Jakarta

\begin{tabular}{cccc}
\hline Skor & Kategorisasi & Frekuensi & $\begin{array}{c}\text { Persentase } \\
(\%)\end{array}$ \\
\hline $\mathbf{X}>\mathbf{1 3 2 , 5}$ & Tinggi & 50 & 100 \\
$\mathbf{X}<\mathbf{1 3 2 , 5}$ & Rendah & - & - \\
Jumlah & $\mathbf{5 0}$ & $\mathbf{1 0 0}$ \\
\hline
\end{tabular}

Hasil perhitungan kategorisasi skor kecerdasan emosional berdasarkan kategorisasi dengan asumsi data berdistribusi normal menunjukkan bahwa 50 responden memiliki skor kecerdasan emosional dengan kategori tinggi.

\section{Pembahasan}

Berdasarkan pengolahan data yang telah dilakukan dengan teknik statistik deskriptif, hasil pengkategorisasian skor kecerdasan emosional secara keseluruhan menunjukkan bahwa di SMKN 1 Jakarta cenderung didominasi oleh siswa yang memiliki skor kecerdasan emosional dengan kategori tinggi.

Siswa yang tinggi kecerdasan emosionalnya, secara sosial mantap, mudah bergaul dan jenaka, tidak mudah takut atau gelisah. Mereka berkemampuan besar untuk melibatkan diri dengan orang-orang atau permasalahan, untuk memikul tanggung jawab dan mempunyai pandangan moral, mereka simpatik dan hangat dalam hubunganhubungan mereka. Kehidupan emosional mereka kaya tap wajar, mereka merasa nyaman dengan dirinya sendiri, dengan orang lain, dan dunia pergaulan lingkungannya.

Siswa dengan keterampilan emosional yang berkembang baik berarti kemungkinan besar ia akan berhasil dalam pelajaran, menguasai kebiasaan pikiran yang mendorong produktivitas mereka. Tingginya kecerdasan emosional siswa tidak terlepas dari faktor-faktor yang mempengaruhi perkembangan kecerdasan emosional siswa. Kecerdasan emosional dapat dipengaruhi oleh beberapa faktor yaitu faktor internal (faktor pembawaan yang bersifat genetik) dan faktor eksternal (faktor yang mempengaruhi perkembangan kecerdasan seseorang secara akumulatif sejak kecil seperti pendidikan dan pengalaman yang dimiliki seseorang). 


\section{Kesimpulan}

Berdasarkan hasil penelitian yang dilakukan dalam menganalisis gambaran kecerdasan emosional siswa SMKN 1 Jakarta, maka dapat disimpulkan sebagai berikut :

Gambaran kecerdasan emosional pada siswa SMKN 1 Jakarta tahun 2012 cenderung tinggi. Hal ini menunjukkan bahwa siswa SMKN 1 Jakarta mampu mengenali, mengontrol emosi dan memusatkan pikiran pada pelajaran serta dapat mengekspresikan sesuai dengan aturan yang berlaku di lingkungannya.

\section{Daftar Pustaka}

Goleman, Daniel. (2003). Emotional Intelligence, terjemahan oleh T. Hermaya, Jakarta: Gramedia.

Hutapea MBA, Parulian \& Dr. Nurianna Thoha MBA. (2008). Kompetensi Plus. Jakarta: Gramedia Pustaka Utama.

J. Stein, Steven dan Book, Howard E. (2002). Ledakan EQ. Bandung: Kaifa

Papalia, Diane E., Sally Wendkos Olds, dan Ruth Duskin Feldman. (2008). Human Development (Psikologi Perkembangan), terjemahan A. K. Anwar. Jakarta: Kencana.

Santrock, John W. (2002). Life-Span Development Perkembangan Masa Hidup, Jilid II. Jakarta: Erlangga.

Sarwono, Sarlito W. (2002). Psikologi Remaja, Edisi Revisi.

Semiawan, Conny R. (1997). Perspektif Pendidikan Anak Berbakat. Jakarta: PT. Gramedia Widiasarana Indonesia.
Shapiro, Lawrence E. (2003). Mengajarkan Emotional Intelligence pada Anak, terjemahan Alex Tri Kantjono. Jakarta: Gramedia.

Sitohang, Kasdin. (1999). Upaya Mengurangi Tawuran Pelajar. Respons, Vol. 4, No. 3.

Wahyuni, Esa Nur. (2005). Model Pelatihan Pengendalian Emosi. Jurnal Ilmiah PsikoEdukasi, Vol. 3, No. 2.

http://smkn1 jakarata.net/index.php?page=berita, diakses pada tanggal 12 Juli 2012, pukul 14.00 .

http://www.boedoet19a.com/2012/01/ada-mesinboedoet-di-mobil-esemka.html, diakses pada tanggal 12 Juli 2012, pukul 14.00 .

http://www.boedoet19a.com/2012/01/anakboedoet-dari-atwuran-hingga-kiat.html, diakses pada tanggal 12 Juli 2012, pukul 14.00 . 